\title{
Ethnomathematics in Creating Tanjak from Tanjungpinang
}

\author{
Febrian Febrian, Puji Astuti, Susanti Susanti \\ \{ febrian@umrah.ac.id,pujiastuti@umrah.ac.id, shanty@umrah.ac.id\}
}

Raja Ali Haji Maritime University

\begin{abstract}
Several preliminary studies have found the importance and promising effect of ethnomathematics in mathematics education. Therefore, this research aims to identify and describe the ethnomathematics in creating Malay male headgear called tanjak. This ethnography research collects data from local creators tanjak in Tanjungpinang, Riau Archipelagic Province through observation, interview, and document. The data collected were processed through reduction, presentation, and drawing conclusions. The results showed that some types of mathematical activities, such as creating rectangular and triangular shape, halving plane area, plane symmetry, measuring the length using standard and non-standard units, and generating a relationship between the length of cloth and predicted of an average person's head circumference are used to create tanjak.
\end{abstract}

Keywords: ethnomathematical research; creating tanjak; mathematical activities

\section{Introduction}

According to E.B. Tylor, culture is the totality of human activities, including knowledge, belief, art, morals, law, customs, and other habits [1], [2]. Linton conveyed that it is a configuration of learned behavior and behavioral outcomes whose elements are shared and transmitted by community members [3]. Therefore, culture can be defined as a way of life essentially shared by a group of people or a nation and passed down from one generation to another. It plays a very important role in human life with the ability to control the behavior of a group of people.

Conversely, behavior is also associated with how people think and react to their environment when faced with problems. Mathematics is one of the common tools used to determine the solution to problems. Many sources reported that it is used to illustrate the ways and techniques used to carry out daily activities developed and carried out by humans to respond to the environment. These include explaining, understanding, experiencing, and finding solutions to surrounding phenomena [4], [5], [6], [7].

According to James, mathematics is a science that discusses the shape, magnitude, arrangement, and concepts and logic related to one another [8]. Mathematics is based on real results and human thoughts related to ideas, processes, and reasoning [9], [10]. Furthermore, it is integrated, influenced, and developed in culture, covering historical, environmental, social, and geographical aspects [7]. For these reasons, mathematics and culture are closely related to each other, and this connection is known as ethnomathematics. 
Ethnomathematics is the research of mathematics, which reflects cultural considerations with understanding the reasoning and mathematical systems [11]. It is a way of learning and combining ideas, ways, and techniques previously undertaken, practiced, and developed by groups or members of different cultures [6], [7]. These standpoints inform that mathematics is practiced and developed within the activities of a group of people, hence, it is rooted in the everyday life activities of humans.

On the other hand, the purpose of understanding ethnomathematics is associated with the ability to change the perspective and concept of mathematics, which is only viewed as a scientific discipline. According to preliminary studies, ethnomathematics plays an important role in mathematics education. [12] stated that it is related to the local culture of researching and teaching mathematics in society. Ethnomathematics tries to relocate mathematics to be based on different cultures by accommodating different ways, ideas, and techniques for students to become critical reasoners, democratic, and tolerant [7], [13]. Therefore, it can be the solution to teaching mathematics to get students motivated and understand in-depthly.

Furthermore, ethnomathematics is always addressed to educate those that are unaware of such mathematics-related intellectuality perceived from daily activity. In fact, on separate occasions, mathematics is described as ready-made knowledge gained while having a formal education in school and as a culture-free subject that is not related to the reality and activity of daily life [14]. Hence, it is considered a difficult and meaningless subject to learn [15]. Finally, it is important to understand the concept of ethnomathematics to educate people and provide a meaningful contextual of mathematics. Many studies have identified and described ethnomathematics as a rich cultural and natural setting in some places, especially in Indonesia.

Several preliminary research on ethnomathematics have been conducted in various places in Indonesia. [16] found mathematical concepts in the Balinese calendar system, while the geometrical patterns were discovered in making Batik in Javanese culture [17]. [18] also explored the mathematical concepts within the daily practice in Sundanese culture. A more recent research by [19] also found some mathematical concepts associated with the local activity of catching fish at the Musi river. Subsequently, [20] found that the ethnomodelling developed by people in Yogyakarta is related to Pranatamangsa system and the birth-death ceremonial.

This rapid increase in ethnomathematics research performed in several places triggers further research in other places such as Riau Archipelagic Province. Research by [15] found rich mathematical concepts in designing and creating a kite named Wau by local people of Lingga due to its length, ratio, proportion, relationship, and linear equation modelling.

The expansion of ethnomathematics is also undertaken in Tanjungpinang, a province with many cultural aspects. One of them is the famous male headgear called tanjak, which is usually used by local people in several ceremonial events. There are many shapes of tanjak, which are dependent on the wearer and the event. One of them is called Elang menyongsong angina tanjak, with a triangular-based shape on its top. Many local people show their skill in creating this kind of tanjak and sell them through the stores. The highly recognizable piece of art from this city makes it possible to be explored. Therefore, this current research tried to identify and describe the mathematical activity or concepts in creating tanjak by local people of Tanjungpinang.

\section{Research Method}

This research used the ethnographic method because it aligns to identify and describe ethnomathematics which includes exploration of ideas, methods, and techniques of a cultural 
community [21], [22]. Ethnographic comprises seven main descriptions: language, the system of technology, economics, the organization of society, knowledge, art, and religion [23]. Based on these descriptions, this research mainly focuses on art by investigating the mathematics behind the process of creating tanjak. Data were collected from local manufacturers of tanjak in Tanjungpinang through observation, interviews, and documentation to identify the underlying ethnomathematics. The creator's name is Mrs. Muarni.

The data obtained from the instruments were analyzed based on the ethnographic research, according to Spradley. [24] designed the data analysis into four, namely domain, taxonomic, componential and cultural theme. In each analysis, data reduction, presentation and conclusion were performed. Finally, all processes were directed to identify the ethnomathematics needed to create tanjak and provide ideas of how this research was conducted. Table 1 shows an overview of this recent ethnographical research.

Table 1: Overview of an ethnographic research of creating tanjak

\begin{tabular}{|c|c|c|c|c|}
\hline $\begin{array}{l}\text { Guiding } \\
\text { Questions }\end{array}$ & Initial Responses & Analysis Stage & Point of View & Activity \\
\hline $\begin{array}{l}\text { Where to } \\
\text { start } \\
\text { analyzing } \\
\text { it? }\end{array}$ & $\begin{array}{l}\text { In the activities of } \\
\text { creating tanjak by the } \\
\text { craftsman in } \\
\text { Tanjungpinang the } \\
\text { associated potential } \\
\text { mathematical } \\
\text { practices } \\
\text { analyzed }\end{array}$ & Domain & Culture & $\begin{array}{l}\text { Carrying out the } \\
\text { observation and } \\
\text { interview with } \\
\text { the local people of } \\
\text { Tanjungpinang as } \\
\text { the creators }\end{array}$ \\
\hline $\begin{array}{l}\text { How to } \\
\text { look at it? }\end{array}$ & $\begin{array}{lr}\text { Looking into the } \\
\text { aspect of creating } \\
\text { tanjak by the } \\
\text { craftsman } \\
\text { Tanjungpinang in } \\
\text { determine } \\
\text { potential the } \\
\text { mathematical } \\
\text { practices }\end{array}$ & Taxonomy & $\begin{array}{l}\text { Alternative } \\
\text { thinking, art as } \\
\text { ethnography } \\
\text { description }\end{array}$ & $\begin{array}{l}\text { Determining the } \\
\text { potential ideas, } \\
\text { ways, or techniques } \\
\text { used by craftsmen in } \\
\text { creating tanjak } \\
\text { related to } \\
\text { mathematical } \\
\text { practice or activities }\end{array}$ \\
\hline What is it? & $\begin{array}{l}\text { Evidence } \\
\text { (Mathematical } \\
\text { activities/concepts as } \\
\text { the outcome of } \\
\text { alternative thinking) }\end{array}$ & Componential & $\begin{array}{l}\text { Mathematics } \\
\text { and } \\
\text { Mathematical } \\
\text { philosophy }\end{array}$ & $\begin{array}{l}\text { Recognizing and } \\
\text { distinguishing } \\
\text { potential specific } \\
\text { characteristics in the } \\
\text { activity of creating } \\
\text { tanjak related to } \\
\text { mathematics }\end{array}$ \\
\hline $\begin{array}{l}\text { What does } \\
\text { it imply? }\end{array}$ & $\begin{array}{l}\text { The value of culture } \\
\text { underresearch }\end{array}$ & Cultural Theme & Anthropologist & $\begin{array}{l}\text { Describing the } \\
\text { ethnomathematics } \\
\text { of creating tanjak by } \\
\text { focusing on the } \\
\text { relationship between } \\
\text { activities and } \\
\text { mathematical ideas } \\
\text { or concepts. }\end{array}$ \\
\hline
\end{tabular}




\section{Result and Discussion}

Observation and interviews were used to determine the processes and techniques in creating tanjak. These initial processes were followed by recognizing the potential mathematical activities or concepts rooted in creating tanjak described in the following stages.

\subsection{Measuring and cutting clothes}

Tanjak is created using two pieces of cloth, the first is a soft material used to cover the outer layer. The second cloth is a harder material, and it is treated as the inner layer that makes tanjak look rigid. The common shape of the top part is in a triangular form that affects the cutting process of cloth by the craftsman.

The choice of a square shape for soft cloth is because it is easy and convenient for symmetrical folding. In obtaining this shape, firstly, the length of the sides of the cloth to be cut is measured. The common dimension chosen for the outer layer cloth is $75 \mathrm{~cm} \mathrm{x} 75 \mathrm{~cm}$, which is a standard unit. However, the choice of the length will later be discussed in the last step of creating tanjak. The outer layer of cloth is shown in Figure 1.

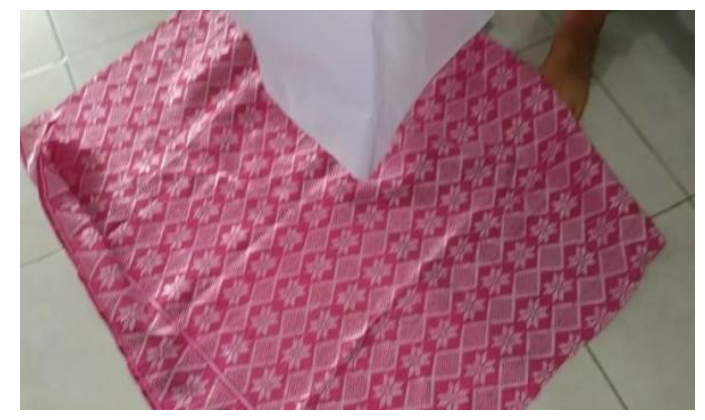

Fig 1: Outer layer of tanjak

As previously stated, soft cloth is used to cover the tanjak, while a harder one is applied to the inner layer. Its function is to give the tanjak a sturdy and upright look, hence the inner cloth should be cut in a triangular shape. According to the craftsman, the inner layer needs to be half of the size of the outer layer, which is in a square shape. Furthermore, the creator needs to cut the inner layer by halving the size of the outer part into an isosceles right-angled triangle. Later, the harder layer is covered by folding the soft square-shaped cloth on the diagonal symmetry. Figure 2 shows the process cut the cloth into an isosceles and right-angled triangle.
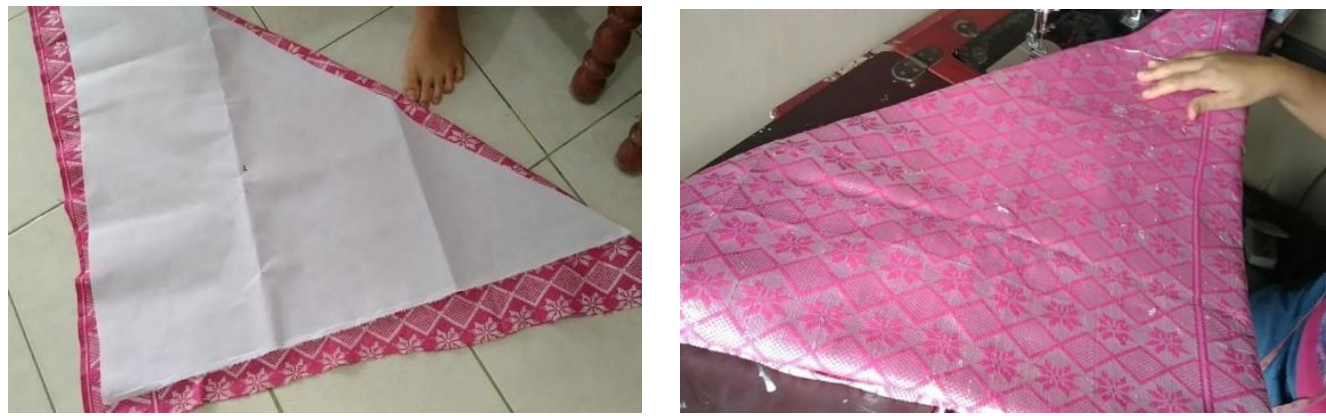
Fig 2: Harder cloth for inner layer cut in an isosceles right-angled triangle from which later be the fill

\subsection{Folding cloth to create the final shape of tanjak}

Folding the cloth starts from the hypotenuse side of the isosceles right-angled triangle by creating a belting component of tanjak. During the folding process, the width of every fold is measured using three fingers simultaneously brought near, which is a non-standard unit, as shown in figure 3. To make the top part proportional to the overall body, it is folded five times to obtain the final process, as shown in figure 3.
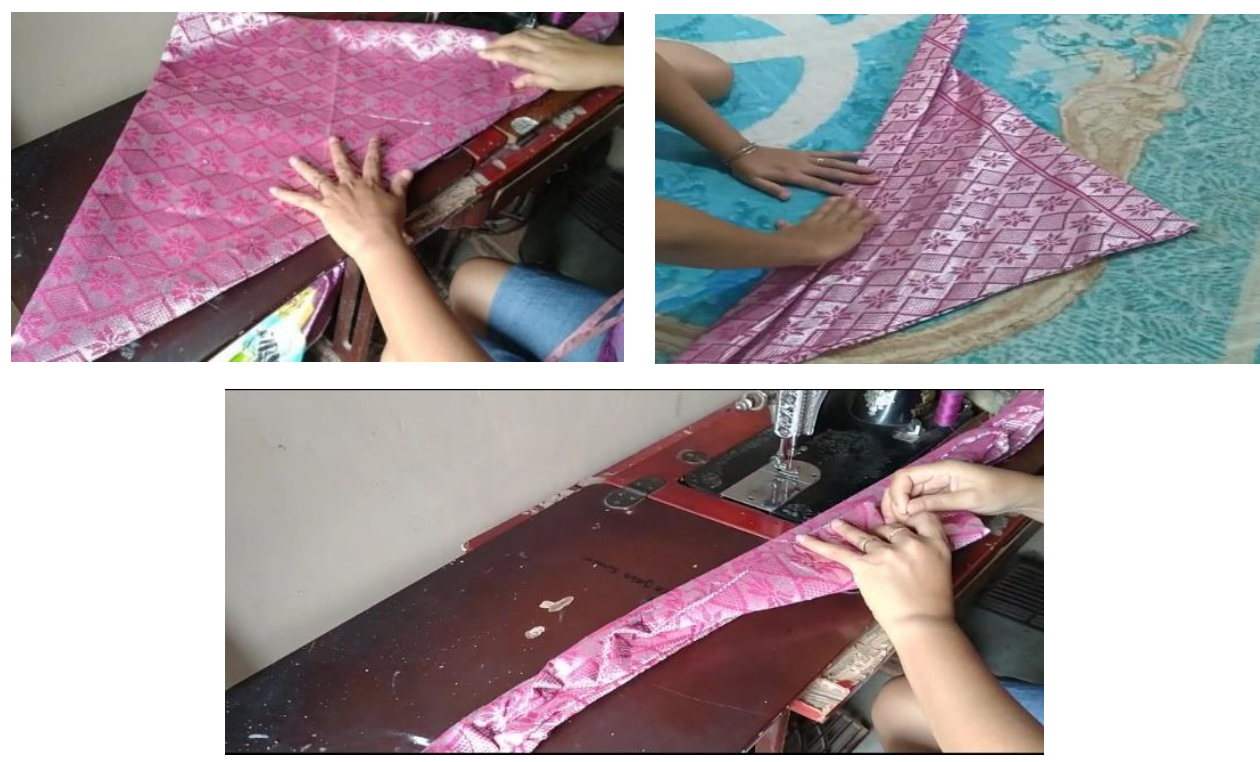

Fig 3: Folding the cloth

The process shows that the total length of all folds occupies almost one-third of the hypotenuse, which is equivalent to the average length of an adult's three fingers of approximately 6-7 cm. The decision to use three fingers together in five-time folds makes sense since two-thirds of the unfolded area is the top part.

Moreover, the process entails that the choice leads to the way of thinking around the 
maximum number of the fold, which is relative to the length of the triangle's hypotenuse, as shown in figure 4 .
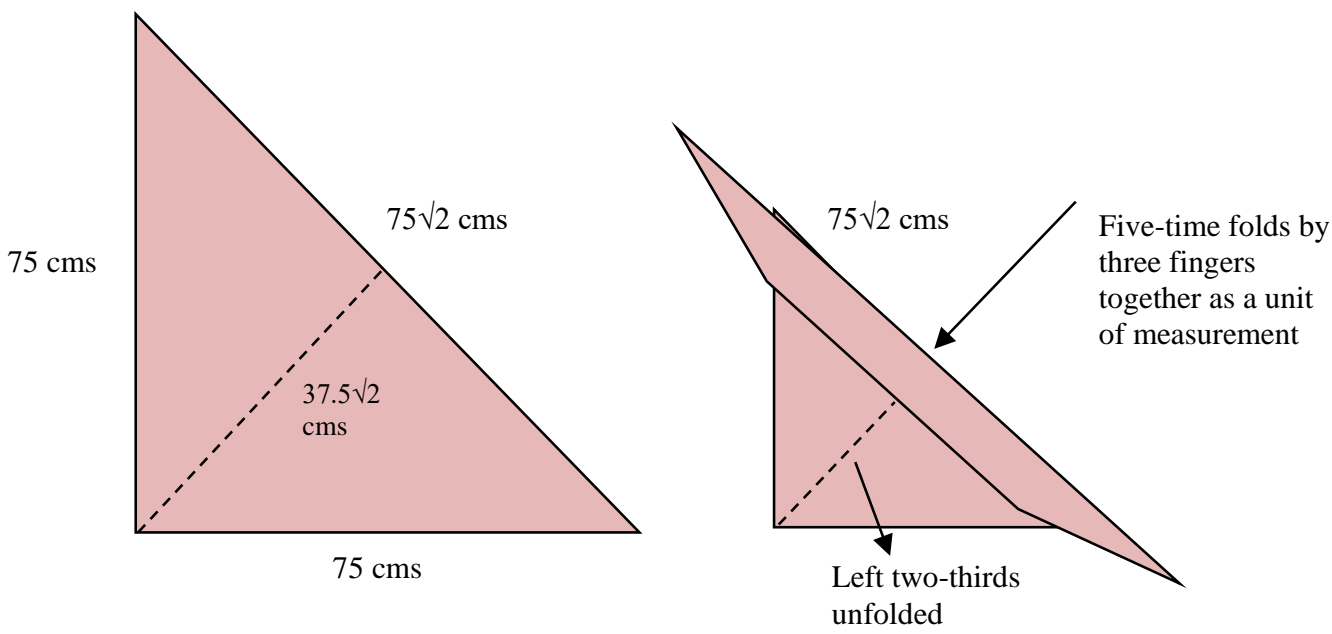

Fig 4: The before-after look of tanjak in the folding process

After achieving the shape, the craftsman irons all body to make the cloth sturdy. The next step is creating the function of the belt from the folded section of the tanjak.

\subsection{Creating the head belt of tanjak}

The final look of tanjak as the result of the previous step produces an easy belt-like function, hence length is adjustable to fit the circumference of user head, as shown in figure 5.
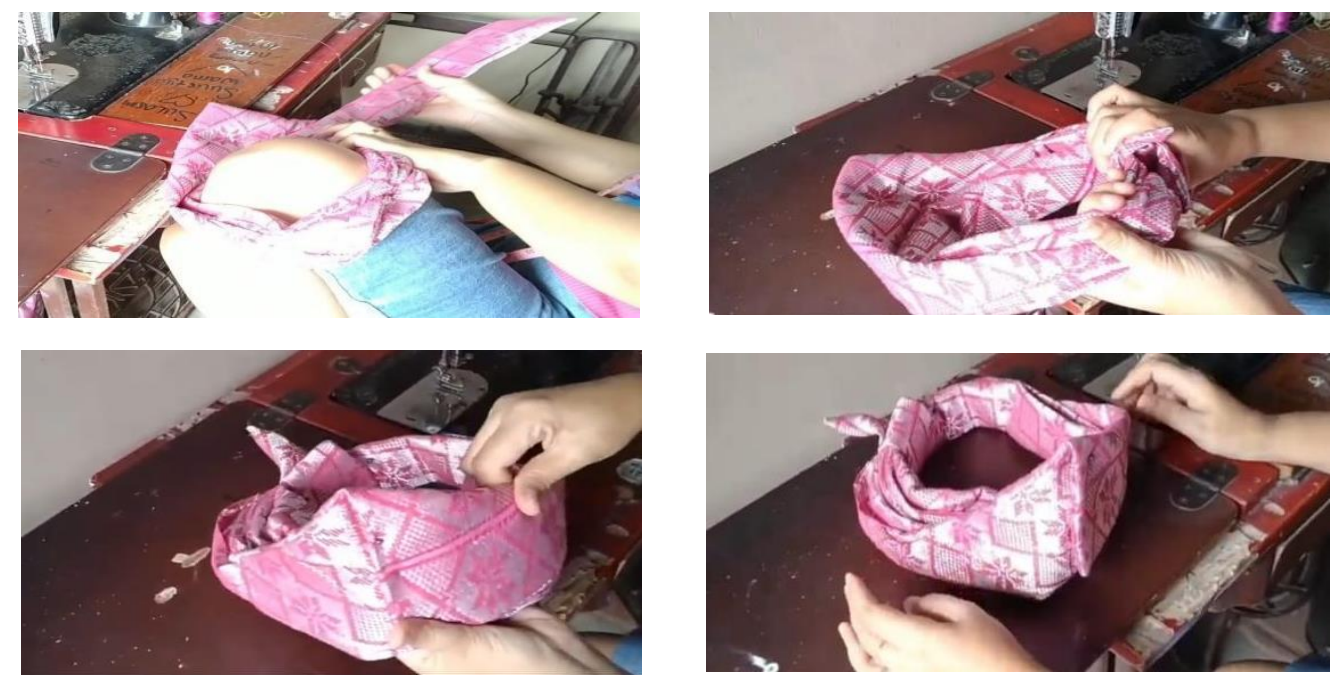
Fig 5: Creating head belting component of tanjak

To create the belt, the folded part is rolled and tied both tips, using an average circumference length of $55 \mathrm{~cm}$, thereby creating a knot, which enables users to adjust the belt to fit their head. Furthermore, a side length of $75 \mathrm{~cm}$ will result in $75 \sqrt{2} \mathrm{~cm}$ of the hypotenuse, making the belt adjustable. Hence this way of thinking actually reveals the idea of connecting each length of the element. The length of the soft side cloth is based on the idea of the length of the circumference of the average head of a person.

Table 2 provides an overview of the ethnomathematical research in creating tanjak.

Table 2: Identified ethnomathematics in creating tanjak

\begin{tabular}{|c|c|c|}
\hline Activities & $\begin{array}{c}\text { Mathematical ideas, ways, } \\
\text { techniques }\end{array}$ & $\begin{array}{c}\text { Emerging mathematical } \\
\text { concepts }\end{array}$ \\
\hline $\begin{array}{l}\text { Measuring and cutting } \\
\text { clothes }\end{array}$ & 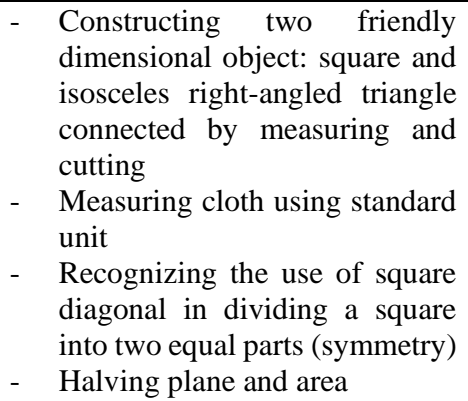 & $\begin{array}{l}\text { - The relationship between } \\
\text { plane figures (square and } \\
\text { isosceles right-angled } \\
\text { triangle) and their derived } \\
\text { characteristics (sides, } \\
\text { diagonals, hypotenuse) } \\
\text { - Length measurement using a } \\
\text { non-standard unit } \\
\text { - Diagonal symmetry } \\
\text { - Area of a plane figure }\end{array}$ \\
\hline $\begin{array}{l}\text { Folding cloth to create } \\
\text { final shape of tanjak }\end{array}$ & $\begin{array}{l}\text { - Using three fingers together } \\
\text { (Tiga jari dirapatkan) as a non- } \\
\text { standard unit to determine the } \\
\text { width or length of the tanjak } \\
\text { - } \begin{array}{l}\text { Deciding the number of folding } \\
\text { needed }\end{array}\end{array}$ & $\begin{array}{l}\text { - Length measurement using a } \\
\text { non-standard unit } \\
\text { - The comparison between the } \\
\text { result of length measurement } \\
\text { using standard and non- } \\
\text { standard units }\end{array}$ \\
\hline $\begin{array}{l}\text { Creating the head belt } \\
\text { of tanjak }\end{array}$ & $\begin{array}{l}\text { - Generating the relationship } \\
\text { between the length of cloth and } \\
\text { predicting the circumference of } \\
\text { a person's head }\end{array}$ & $\begin{array}{l}\text { - Length prediction, } \\
\text { comparison, and proportion } \\
\text { - } \text { Length comparison }\end{array}$ \\
\hline
\end{tabular}

The results of the research indicate that there are visible mathematical activities in creating tanjak, which include ideas, ways, and techniques. Those mathematical activities are measuring, cutting, and folding cloth to create the final shape of tanjak. These mathematical activities emerge some mathematical concepts categorized in three general topics, namely length measurement, plane figure, and comparison.

The art of creating tanjak is a rich source of ethnomathematical research. In a previous research on Malay songket weavers, some basic concepts were found, such as measurement, estimation, and transformation geometry [25]. [26] found the mathematical activities in Bali 
woven handicraft, while Risdiyanti \& Prahmana (2017) discovered the geometrical patterns used in making Batik. Recently, [27] found mathematical activities in Jepara sculpture.

Conversely, the most noticeable part of the research in creating tanjak is that the mathematical activities were mostly around the length measurement. This is because almost every step in creating tanjak contains the activity of measuring the length. Similar results are also shown by some ethnothematical research by [25], [15], [27], in which measurement, especially length, becomes the most frequent aspect. The measurement is a very basic form of human activities frequently performed in daily life practices. Therefore, almost every ethnomathematical research ever conducted found that length measurement is the main research result.

This research provides information on the existence of mathematics in the practice of people's lives. It indicates that mastering mathematics more formally can be supported by everyday life phenomena, which are the starting point for its learning. Therefore, this led to the promising effect associated with ethnomathematics in mathematics education. Ethnomathematics fits well within the constructivist theory of having students build understanding and knowledge through what they have already learned and exposed to previously [28]. Several research has demonstrated that integrating ethnomathematics in mathematics teaching and learning has assisted teachers and students in contexts of ideas, ways, techniques used in real life to enhance interest, understanding, and creativity [29], [4], [5].

Moreover, the present research revealed that length measurement is a frequent emerging mathematical idea among others. It is a basic and common practice conducted by people in a community. Therefore, taking the phenomena as the potential mathematics learning context of length measurement, contained in curriculum, and well explored in teaching and learning process is a good idea. Among measurement domains, length is extremely important for students to understand basic ideas and construct bases for advanced topics, such as area and volume [30].

\section{Conclusion}

In conclusion, some mathematical activities, such as creating rectangular and triangular shape, halving plane area, symmetry, measuring the length using standard and non-standard units, and generating a relationship between the length of cloth and the predicted average of a person's head are used to measure, cut, fold and cut the tanjak. The results indicate that creating tanjak is an activity-rich with mathematical concepts such as length measurement, plane figure, and comparison. However, further research needs to be carried out to determine the potential upbringing of mathematics education.

\section{References}

[1] Rachmawati, I. Eksplorasi etnomatematika masyarakat Sidoarjo. MATHEdunesa. 2012; 1(1): 1-8.

[2] Ratna, N. K. Sastra dan cultural studies: representasi fiksi dan fakta. Yogyakarta: Pustaka Pelajar; 2005

[3] Kistanto, N. H. Tentang konsep kebudayaan. Sabda: jurnal kajian kebudayaan. 2017; 10(2): 1-11. https://doi.org/10.14710/sabda.v10i2.13248 
[4] Freudenthal, H. Revisiting mathematics education: China lectures. Vol. 9. Cham: Springer Science \& Business Media; 2006

[5] D'Ambrosio, U. Ethnomathematics: perspectives. north American study group on ethnomathematics. News. 2007 2(1):

$2-3$

http://citeseerx.ist.psu.edu/viewdoc/download?doi=10.1.1.417.9195\&rep=rep1\&type=pdf

[6] Rosa, M., \& Orey, D. C. State of the art in ethnomathematics. In M. Rosa, U. D'Ambrosio, D. C. Orey, L. Shirley, W. V. Alangui, P. Palhares, \& M. E. Gavarrete (Eds.). Current and future perspectives of ethnomathematics as a program. Cham: Springer; 2016. 11-37. https://doi.org/10.1007/978-3-319-30120-4_3

[7] D'Ambrosio, U. An overview of the history of ethnomathematics. In M. Rosa, U. D'Ambrosio, D. C. Orey, L. Shirley, W. V. Alangui, P. Palhares, \& M. E. Gavarrete (Eds.), Current and future perspectives of ethnomathematics as a program. Cham: Springer; 2016. 5-10. https://doi.org/10.1007/978-3-319-30120-4_2

[8] Rahmah, N. Hakikat pendidikan matematika. Al-Khwarizmi: Jurnal Pendidikan Matematika Dan Ilmu Pengetahuan Alam. 2018; 1(2): 1-10. https://doi.org/10.24256/jpmipa.v1i2.88

[9] Ruseffendi, E.T. Pengantar kepada membantu guru mengembangkan kompetensinya dalam pengajaran matematika untuk meningkatkan CBSA. Bandung: Tarsito; 1988.

[10] Siagian, M. D. Kemampuan koneksi matematik dalam pembelajaran matematika. MES: Journal of Matematics Education and Science2. 2016; 2(1): 58-67.

[11] D'Ambrosio, U. Ethnomathematics and its place in the history and pedagogy of mathematics. For the learning of mathematics.1985; 5(1): 44-48. https://www.jstor.org/stable/40247876

[12] Shirley, L. Ethnomathematics as a fundamental of instructional methodology. Zdm. 2001; 33(3): 8587.

[13] Zevenbergen, R. Changing contexts in tertiary mathematics: Implications for diversity and equity. In D. Holton, M. Artigue, U. Kirchgräber, J. Hillel, M. Niss, \& A. Schoenfeld (Eds.). The teaching and learning of mathematics at university level. Dordrecht: Springer; 2001. 13-26. https://doi.org/10.1007/0-306-47231-7 2

[14] Rosa, M., \& Orey, D. Ethnomathematics: the cultural aspects of mathematics. Revista Latinoamericana de Etnomatemática: Perspectivas Socioculturales de La Educación Matemática. 2011; 4(2): 32-54.

[15] Febrian, F. Recognizing ethnomathematics in wau kite and corak-ragi of tenunmelayu from kepulauan Riau province and using its potentials towards learning of school mathematics. In Sriwijaya University Learning and Education International Conference Vol. 2, No.1. Palembang: Sriwijaya University; 2016. 337-358

[16] Suarjana, I. M., Suharta, I. G. P., \& Japa, I. G. N. Etnomatematika sistem kalender Bali. In Seminar Nasional Riset Inovatif II, 2: 2014. 177-182.

[17] Risdiyanti, I., \& Prahmana, R. C. I. Ethnomathematics : Exploration in Javanese culture. Journal of Physics: Conference Series. 943(1); 2017. p. 012032. https://doi.org/10.1088/17426596/943/1/012032

[18] Abdullah, A. S. Ethnomathematics in perspective of Sundanese. Journal on Mathematics Education. 2017; 8(1): 1-16. https://doi.org/http://dx.doi.org/10.22342/jme.8.1.3877.1-15

[19] Malalina, M., Putri, R. I. I., Zulkardi, Z., \& Hartono, Y. (2020, October). Ethnomathematics of fish catching exploration in Musi River. In Journal of Physics: Conference Series (Vol. 1663, No. 1). IOP Publishing; 2020. P. 012007

[20] Prahmana, R. C. I., Yunianto, W., Rosa, M., \& Orey, D. C. Ethnomathematics: Pranatamangsa system and the birth-death ceremonial in Yogyakarta. Journal on Mathematics Education. 2021; 12(1): 93-112.

[21] Ascher, M., \& D'Ambrosio, U. Ethnomathematics: a dialogue. for the learning of mathematics. 1994; 14(2): 36-43. https://www.jstor.org/stable/40248114

[22] Shirley, L., \& Palhares, P. Ethnomathematics and its diverse pedagogical approaches. In M. Rosa, U. D’Ambrosio, D. C. Orey, L. Shirley, W. V. Alangui, P. Palhares, \& M. E. Gavarrete (Eds.). Current and Future Perspectives of Ethnomathematics as A Program. Cham: Springer; 2016. 13-17. https://link.springer.com/content/pdf/10.1007\%2F978-3-319-30120-4.pdf 
[23] Koentjaraningrat. Pengantar llmu antropologi [introduction to anthropology]. Yogyakarta: Rineka Cipta; 2015.

[24] Spradley, J. P., \& McCurdy, D. W. Anthropology: the cultural perspective. reissued long grove. IL: Waveland Press; 1989.

[25] Embong, R., Maizan, N., Aziz, A., \& Abd, Z. An insight into the mathematical thinking of the Malay songket weavers. Procedia Social and Behavioral Sciences. 2010;8(5): 713-720. https://doi.org/10.1016/j.sbspro.2010.12.099

[26] Puspadewi, K. R., \& Putra, I. G. N. N. Etnomatematika di balik kerajinan anyaman Bali. Jurnal Matematika. 2014; 4(2): 80-89.

[27] Utami, R. N. F., Hermanto, R., Muhtadi, D., \& Sukirwan, S. Etnomatematika: eksplorasi seni ukir Jepara. JP3M (Jurnal Penelitian Pendidikan dan Pengajaran Matematika). 2021; 7(1): 23-38.

[28] Brandt, A., \& Chernoff, E. J. The importance of ethnomathematics in the math class. 2015.

[29] D'Ambrosio, U. Literacy, matheracy, and technocracy: A trivium for today. Mathematical Thinking and Learning. 199; 1(2): 131-153. https://doi.org/10.1207/s15327833mt10102_3

[30] Tan-Sisman, G., \& Aksu, M. The length measurement in the Turkish mathematics curriculum: its potential to contribute to students learning. International Journal of Science and Mathematics Education. 2012; 10(2): 363-385. 